\title{
Lumen
}

Selected Proceedings from the Canadian Society for Eighteenth-Century Studies

\section{'No Party favour'd, no Designs in view' : Female Rakes and Heroes, Politics and Power in Delarivier Manley's Heroic Drama}

\section{Elizabeth Hollis-Berry}

Volume 19, 2000

Material Productions \& Cultural Construction

Culture matérielle \& Constructions discursives

URI : https://id.erudit.org/iderudit/1012323ar

DOI : https://doi.org/10.7202/1012323ar

Aller au sommaire du numéro

Éditeur(s)

Canadian Society for Eighteenth-Century Studies / Société canadienne d'étude du dix-huitième siècle

ISSN

1209-3696 (imprimé)

1927-8284 (numérique)

Découvrir la revue

Citer cet article

Hollis-Berry, E. (2000). 'No Party favour'd, no Designs in view' : Female Rakes and Heroes, Politics and Power in Delarivier Manley's Heroic Drama. Lumen, 19, 171-186. https://doi.org/10.7202/1012323ar

Copyright (C) Canadian Society for Eighteenth-Century Studies / Sociéte canadienne d'étude du dix-huitième siècle, 2000
Ce document est protégé par la loi sur le droit d'auteur. L'utilisation des services d'Érudit (y compris la reproduction) est assujettie à sa politique d'utilisation que vous pouvez consulter en ligne.

https://apropos.erudit.org/fr/usagers/politique-dutilisation/ 


\title{
12. 'No Party favour'd, no Designs in view': Female Rakes and Heroes, Politics and Power in Delarivier Manley's Heroic Drama
}

\author{
What can poor We expect, in such a Case? \\ Dare English Tragedy plead Hopes of Grace? \\ No Party favour'd, no Designs in view, \\ To make Old Times, club Faction with the New, \\ No double soft Entenders to excite, \\ No Politicks to please the Wise to Night, \\ Such a dull Play, could any Modern write? \\ (Lucius, The First Christian King of Britain, Prologue ii)
}

These lines from the Prologue 'by a Young Gentleman,' with their disingenuous appeal for clemency from an audience steeped in 'Scandal, Politics, and Traps,' perform a rhetorical double act, agitating politically even before the action of Delarivier Manley's last, most successful play begins. The combination of anaphora with denial draws attention to those very theatrical strategies at which Manley excelled. In downplaying the role of 'Faction,' a royalist code-word for Whig rabble-rousing, this prologue (like many others throughout the period) also announces the playtext's Tory political affiliation. ${ }^{1}$ Yet the verse is clearly ironic, since it professes a dramaturgical dullness quite the reverse of Manley's always political designs. Agitation was Manley's business. Opening up fissures here, contradictions there, bursting at the seams with 'double soft Entenders,' paradox and 'Politicks,' her plays, prose fiction, and pamphlets written for the Tory cause often agitate against the surface of party political values. Manley's writing, while seeming to endorse the power relations of cavalier 'Old Times,' contests and re-negotiates the old, creating 'the New,' a revolutionary space for women as rakes and heroes. $^{2}$

Whether writing about party politics or sexual politics, positioning herself as a Tory royalist or as an emergent woman overturning gender roles, Manley continues a process started by Aphra Behn. Writing for the 
theatre proved as desirable for Manley as it had for Behn in the 1670s, since, as Behn's dramatic writing experience demonstrated (and her claims in her preface to The Dutch Lover asserted), the drama seemed a particularly accessible genre for a woman writing for money and without the benefit of a masculine (ergo classical) education, playing for publicly rather than privately-funded profit. For Behn, as Susan Owen argues, the relationship between royalism and feminism, while empowering in some ways, is also 'hard to reconcile' (Restoration Theatre and Crisis 160). Although clearly focussed on a period before Manley was even writing, Owen's approach to the plays of the Exclusion Crisis offers a profitable line of enquiry as far as these later heroic tragedies are concerned, for she advocates a nuanced reading that takes into account the kinds of contradictory constructions also found in Manley's plays:

many plays in this period are critical of misrule in high places, and have the force of opposition without advocating rebellion. Moreover, even when loyal playwrights are straining every nerve to justify the ways of the Stuart monarchy to men, the negative resonance of loyalty to vitiated kings is apparent ... recurring themes are bad fatherhood and the sovereign's unruly passions which jeopardize the state, inability or failure to reward loyal service, and general political impotence or incompetence. (25)

Comparable in key strategies to these earlier dramatists, Manley similarly often situates her criticism of the status quo in a place of apparent moderation - less wild zealotry, more witty polity - while reappropriating that space between for her own distinct voice. I am necessarily limiting my focus to Manley's three heroic tragedies because, like her high-political pamphleteering and satirical scandal-mongering for the Tories, the drama is topical and partisan, politically hot property. Of the contiguous baroque drama Walter Benjamin would say this kind of discourse was stylistically marked by 'agonizing violence' $(49)^{3}$ and insincerity, but more recently Owen has argued that for heroic drama of the Restoration this was actually a ferocious engagement with the discourse of the times and with changing them.

This discursive engagement with the times charts political confusion or violent instability throughout the last decades of the Seventeenth Century, when intrigue followed revolution, division and fear inscribed the body politic. The death of the secretly Roman Catholic Charles II was preceded by widespread fears of various plots - Popish or otherwise and succeeded by the openly Catholic James II's harsh suppression of his Protestant nephew Monmouth's Rebellion; Jacobite uprisings against William occurred after his Glorious Revolution in 1689. Such a turbulent political climate was chronicled repeatedly in dramas concerned with 
power relations and the nature of authority, dramas embodying an often heroic excess, their extravagance - according to Susan Staves - reflecting the extravagance and preposterousness of Restoration political experience itself' (48). Cultural anxieties about authority, hierarchy, loyalty, power, and place were insistently played out in the dramatic plots that enacted both Whig and Tory ideologies - the very labels Whig and Tory first coming into use at this time, though with rather more fluid boundaries than ascribed to them later. Indeed, Staves indicates the error in affixing to the period's dramatic writings any twentieth-century associations of Toryism with conservative limitations or Whiggism with liberal freedoms.

The period's dramatic representations of power and place provide clues as to why both Behn and Manley found Toryism a more accommodating space than Whiggism for their feminocentric views. Old cavalier Tory positions (promoting women's active contribution to the royalist cause) were more amenable to these women writers who promoted themselves as female artists on a par with men and for whom Tory ideology allowed more room for creative individualism than Whig (puritan) philosophy offered. Writing of Behn's 'fantasy of a golden age of social and sexual frankness,' Janet Todd emphasizes that such a vision left Behn 'no sympathy with a Whiggish view of political or economic progress' (17). This assertion applies equally well to Manley for whom Tory politics gave her feminist interests more scope. That Toryism more readily negotiated a feminist assertion of sexual and social power is also suggested by Ellen Pollak, who maps the differences between a middle class anxiously marking its status by commodifying women as obedient property - 'the bourgeois myth of passive womanhood' - and a nobility less defined by property (trade or credit) than by 'the secure prerogatives' of birth and land, thus more tolerant towards 'the sexual exuberance and gamesmanship of women' - a salient feature of the period's drama (4). When both Behn and Manley staked a claim for themselves in the male-occupied territory of play-writing, they each expressed a belief in their individual rights to authorship no less than their creative abilities and a repugnance for mass opinion - the authority of the mob. In so doing, their Tory allegiances are spelled out in tandem with their revolutionary (feminist) interests.

Taking into consideration all this discursive potential, a trove of politically rich pickings, why then have Manley's tragedies been given scant attention? Perhaps this neglect has occurred because (as Robert Markley argues of Behn) the ideological battles in which her plays participate 'in terms of her Tory politics, aristocratic apologetics, and feminist sexual ideology' place her 'historically on the losing side' (Cultural Readings 115). Or perhaps, as certain critics imply, it is the case that 
Manley, the notorious Tory hack, imprisoned for her political satire which suggestively opens up feminist spaces in the process of carving up corrupt Whigs, ultimately fails to deliver the radical goods in her final play. From Manley, the disturber, whose political attacks 'incurred the wrath of the government (not to mention Alexander Pope),' complains J. Douglas Canfield, 'one might have expected a more enlightened treatment of gender' in this late heroic drama (Cultural Readings 200). Yet, bearing in mind the interpenetration of party and gender discourses over this period, this apparent inconsistency is precisely why her plays are of interest, tracing as they do a shifting array of gender and party-political tropes.

On Manley's stage one may indeed find hovering a 'genie of emergent bourgeois ideology, particularly concerning the class status of men and the gender status of women,' identifiable in key tropes, such as the uppity self-made woman, and the phallic sword of 'middle class male dominance,' its naked point shrouded by bourgeois 'self-reliance' according to Canfield (Cultural Readings 199). Yet, for all its neat rhetorical strokes, this is not the entire picture. A reading of Manley's first heroic tragedy The Royal Mischief (1696) might find the royal seductress troped - like Dryden's Lyndaraxa - into 'the figure of the uppity woman put in her place by the phallic sword of gender dominance' (Cultural Readings 197). Equally evident, however, in this as in her later plays, are the very contradictions that in a Marxist sense 'borrow' the party political language of royalism - 'names, battle cries and costumes' - from a past Tory golden age, to 'act out the new scene' with a revolutionary potential for gender politics (The Eighteenth Brumaire of Louis Bonaparte 9-10).

Thus appropriating the Old (cavalier costume and rakish rhetoric) for the sake of the New in The Royal Mischief, Manley's seductively transgressive, splendidly wicked, royal rake Homais represents an emergent figure which resists being stopped up, at least for the time being. Whether such a figure, however, embodies the bourgeois trope of the self-made woman or something more subtly disruptive is the point in question. While speculating how the bourgeois trope of self-made man might have been more readily embraced by English society than that of the self-made woman, Canfield also wonders about generic tendencies in the heroic romance to 'contain emergent male individualism by enlisting it in the service of imperialism' (197). This connection between emergent individualism and imperialism suggests another approach to the treatment of Manley's female characters.

My focus on Manley's three tragedies which were staged during three different reigns in 1696,1707, and 1717, readily engages with cultural readings of late seventeenth- and early eighteenth-century drama such as those offered by Owen and Canfield. Whereas Canfield effectively 
traces the possibility of a Foucaultian epistemic shift through tropic analysis, I would question his blanket proposition that after the Glorious Revolution the plays are exclusionary, because in common with other 'serious' drama of the period, these heroic plays 'portray the consolidation of power in the hands of a new (male) elite' and 'their neostoic exemplary morality masks upper middle-class male dominance over gender, class, and even race' (Cultural Readings 196). For it seems to me that this analysis, searching though it is, glosses over contradictions in plays such as Manley's final work for the stage, Lucius, The First Christian King of Britain. Looking for 'a new, bourgeois configuration of discursive elements' in contrast to the aristocratic 'force-field' gripping the elements of official discourse together previously, Canfield claims that in general 'bourgeois ideology freezes out radical potentialities' and in particular, of Manley the political campaigner, her female hero, Rosalinda, 'may be' no more than a (frozen?) 'hopeful' sign for the future (223). Viewed in the context of the three tragedies, however, Rosalinda, the last of Manley's heroic female figures, may turn out to be as provocative politically as is Homais, the rakish first.

While in her prose fiction Manley satirizes Whig lechery (with feminist implications) in the form of ruinous treachery, as distinct from the traditional Tory acceptance of the cavalier libertine, in her first tragedy The Royal Mischief her depiction of the female rake Homais offers the kind of ripe contradiction that allows for both Tory and feminist viewpoints in a kind of revisionary act. Here the gender politics agitate against the familiar party politics, the positive Tory theme of rakishness as class superiority problematized by this confined royal wife's understandable insurrection. Although the errant Homais's disloyalty to her impotent old husband threatens both monarchy and patriarchy, Manley manages to make her so appealing in her hunger to escape a suffocatingly repressive regime that a sympathetic space opens up for this captive figure of youthful sensuality. Thus even while Manley gives voice to women's issues (sexual and personal freedom), this transgressive female character who embodies the seductive potential for such freedoms represents the enemy in party political terms - the Tories throughout the Restoration having shown the family violated by rebels and ambitious plotters (Owen 163).

From the play's outset, in The Royal Mischief Manley demonstrates the obvious spatial limitations placed on Homais - shown fretting in 'A royal Apartment in the Castle of Phasia,' lamenting a doomed passion for her aged husband's nephew, 'such a love, / So hopeless, so fantastic, all my stock / Of youth and charms cannot forbid despair' (1.1.213). Her first words suggest the heroically terminal nature of her disorder - "Tis finished' - and with forlorn irony comment on the expansive power of 
her 'conquering cousin,' his progress only impeded by the 'thick'ning laurels, sprung to stop his passage' which 'turn a necessary march to one / Long solemn triumph' (1.1.212). ${ }^{4}$ Juxtaposing the confined royal enclosure with the triumphal royal progress, Manley's scene implicates an entire cultural hierarchy where the only empire allowed the young woman - who happens to be a princess - is (predictably) the world of 'love's almighty passion' (1.1.212). Spatially and discursively, everything and everyone surrounding her confirm a culturally ordained sphere as narrow as the body she inhabits. Hers, the royal eunuch proclaims, is the place of the heart, where, rather than a body of land, a suitably land-owning body - 'A person fit to fill your royal breast' can be held. Homais may not colonize beyond these walls; her body will be both colonizer and colonized. She banks on this, her power to possess sexually, in a 'stock /Of youth and charms' (1.1.213).

In some of the language's oxymoronic pairings - imperial might with sensual deliquescence - and the metaphors of appropriating heaven itself recalling dialogue in Shakespeare's Antony and Cleopatra, the opening scene presents tropes of imperial power relations. The poetic language is sometimes overblown and frequently paradoxical. Here Acmat, the loyal eunuch, and Homais, the hungry royal wife, map out the cause of her 'Disorder' (1.1.212). This entire exchange between appetitive princess and faithful eunuch foregrounds the antithetical, the contradictory positions of possession and dispossession, presence and absence, liberation and entrapment, all and nothing.

These contradictory positions politically define Homais, whose mysterious sexual power is played off against the unsexed powerlessness of Acmat. Again, producing the double-edged effect of ironic distance coupled with experiential immediacy, Manley gives the recollection of his mistress's desires - her lived experience of rakish possession - to the devoted unmale, non-rake Acmat, who cites his 'long tried service' and secrecy 'Which still, where you're concerned, bids me be dumb, / forget I've life, and ranks me with the dead' (1.1.212). In the play's power relations, then, while Homais in her active pursuit of her own desire is really something, Acmat is both noting and nothing. His apparent function in her life is, according to him, that of a nothing, a cipher, merely noting the signs of imperial appetite, the corporeal territory of a rakish mistress which is her only potential conquest and his only vicarious pleasure: 
My sense had touched the mark,

If that my memory in all its search

Could but have fixed your new disquiets on

A person fit to fill your royal breast.

Osman the new-made Visier you detest,

His cousin Ismael you have enjoyed,

And sure such fires did never wait possession,

Since that, none has approached your royal sight

Fit to give love or to create desire,

Or if there had I soon had marked the man,

For love like yours in absence may be hid,

In presence never!

For all this, Homais could be one of the boys. Acmat implies as much when he associates her with the sun (appropriating - filling - the entire 'Eastern World') and the conquering hero, more precisely Alexander who, while obviously a good catch also represents an equivalent heroic type. When Acmat observes, 'No second Alexander fills the globe,/ No glorious busy hero, to enslave / Your heart at distance, and with unseen fame, /Make conquest easy,' the point about who is enslaving whom remains open to question. As the eunuch goes on to declare, Homais this physically confined figure - compensates erotically for her lack of freedom. While the Prince of Libardian is actively out in the field, amassing territory and honours, the Princess Homais relies on her body for conquest. Her very looks can colonize the globe, shooting fiery 'darts,' bringing light to the darkness, but hers is a passion misplaced since it transgresses established moral and cultural boundaries, setting her outside the feminine tradition.

This reversal of roles problematizes such issues as the male gaze and imperial conquest, particularly when the eunuch goes on to point out the limitations imposed on such 'lawless' feminine desire, 'a woman's love' which paradoxically is so defined only because the 'swelling current will admit no bounds' (1.1.214). The ground the Princess appropriates for herself, however, is the Augustan place of appetitive expansionism, significantly that space commonly claimed by male authority figures (and noted in the image patterns of Augustan male authors by Margaret Anne Doody). Class-centred, acquisitive, cavalier, Homais bristles back at the eunuch's alarmed propriety with raffish hauteur which resounds with a boldness similar to that in Swift's (1693) lines 'To Mr. Congreve,' urging 'Beat not the dirty paths where vulgar feet have trod / But give the vigorous fancy room' (Doody 5). Performed three years after the 1693 date of Swift's verse, Manley's dialogue makes a case for a far more revolutionary daring than Swift or his fellows would 
have cared to own, since these lines belong to an unabashed young woman about to stake her incestuous claim on the forbidden territory of her nephew's comely form:

Thy vulgar soul moves in the common road,

Mine loathes the beaten path and starts aside

To seek new regions out, disgusted with the old,

And now the rich discovery is made,

I'll push the bold adventure on,

And either die or conquer.

We have to remind ourselves that this expansive imperialistic credo characterizes a female figure; whereas these claims might just as well be those of a post-revolutionary male aristocrat, they might also be those of a merchant adventurer (or an aspiring Augustan poet). Could this language then be said to articulate the trope of the Whig self-made woman or that of the appetitive Tory rake? If the contradiction springs from such appetitive discourse originating in a speaker gendered feminine, perhaps this discursively reveals the fissures between Toryism and feminism that Owen finds in Behn's plays (Owen 6).

When we read Homais as a female rake, the question arises about whether this then makes her a monstrosity who will not fit in either political camp - in Tory terms a treasonous rebel, in Whig terms an aristocratic lecher. Although as a woman, Homais is allowed the rare opportunity to flaunt what little power is left to her in an infamous description of her first orgasmic experience represented in terms of sexual property - 'Not vast imagination can define' her 'boundless,' 'mighty' empire (4.1.240) - by implication she is also constructed as monstrous through a hypocritical male character's definition of her libertine sexuality. By placing the predictably defamatory construction in the mouth of Osman, the vacillating Chief Visier, Manley opens up a whole kettle of fishy gender and moral definitions. The not-so-trusty Osman emphasizes a problematic difference between Homais and his would-be paramour Bassima, who is not only too cloyingly virtuous to be true but also promised to the young Prince. Osman's words parrot Tory ideology while maintaining a Whig economy of moral values when he proclaims that indulging passion (a rebellion against established codes of honour) pays less, while staying true to vows of fidelity yields more. The sentiment is almost palpable in these lines addressed to Bassima who has just refused him: 
Rich tears! What power lies in those falling drops.

They rivet me more fast than a thousand chains,

And makes that fate, which now appeared so fair,

Compared with that rich life, which you can give,

Horrid deformed and shocking,

Such as my happier state would most avoid.

Upholding vows, maintaining loyalty, preserving honour, Osman declares, may be the heroic, noble mode of conduct but such actions cost physical privation - the pain of denial twistedly rewarding. This makes Osman a kind of enemy-agent, operating as a royalist mouthpiece with, one suspects, the heart of a puritan zealot, his ventriloquism echoing post-Civil War propaganda methods.

In this particular instance, when the drama discredits not so much the royalist dummy as the hypocrite beneath, Manley satirizes Whig puritanism. The anti-rake puts worth in obedience to royalist standards of loyalty: rebellion means that 'in one short moment' Osman might lose his stake in an imperialist economy or 'Lavish the treasure of my life away' (3.1.237). Bassima also recognizes that she can charge Osman 'by honour, glory, fame,' (the royalist code of conduct) to save her from capitulation, or flying 'to death' in his arms, a space which is figured as ruinous property 'the fatal land' (3.1.237), ownership at a deadly price. Also signalling a satirical twist, Manley's choice of hyperbolical rhetoric suggests a suitably hellish demise for the trespasser with a puritanical bent. The verbal emphasis in Bassima's view of an impending, sinful death - 'Torn in my conscience, mangled in my virtue' - anticipates the staged pyrotechnical fate that awaits her would-be paramour's body which is fired from a cannon in smoking pieces of gore at the play's end.

Juxtaposed with this scene wherein the virtuous Princess Bassima and the Visier agree 'We will be guiltless though unfortunate' (3.1.238) is its ideological antithesis in young Prince Levan's description of unwedded bliss. Levan spells out those transports of delight ensuing from the illicit, incestuous union he has just enjoyed with Homais, his uncle's incomparable wife. So persuasive is the draught of hitherto unknown 'joys' - 'joys untold, unproved, unthought till now,' at least by him - that the lovers are transfigured into 'goddess' and 'god' (3.1.238). Thus elevated beyond their station, in seeing themselves deified, the pair refigure Tory ideals of honour and justice: 'Honour and justice are low sounds, can scarce / Be heard when love is named,' declares Levan in what appears to be the assertion of an anti-royalist creed (3.1.238). The syntactic pointing of these lines situates a Whiggish denigration of aristocratic honour and justice with references to the 
tellingly named Protector - shades of a Cromwellian ghost, actually meaning the Prince of Libardian, the wronged royal uncle/patriarch/husband, who is expected to step aside for these cheating young upstarts. Subsequent dialogue between Homais and Ismael (her former secret lover) spells out the treacherous (and treasonous) bent of this passion:

Oh, did you know the difference

Between a new-born passion, and a former!

Nothing remains but memory and wonder,

Not the least warmth of kind desire or joy.

When Homais sets the unwanted Ismael straight about his role in her busy life, these words resonate with contradictory implications: on the one hand of heroism in the arena of sexual politics - the female rake, claiming her right to libertine freedoms of sexual choice - or on the other, a political slight aimed squarely at the self-made bourgeois nonconformist. Such familiarly rakish sentiments open up ironic fissures of uncertainty which, while they make a space for female experience of physical, sexual power, also locate that power in the contentious milieu of nonconformist ideology. The rhetoric here, as elsewhere in the play is part Tory polemic, part feminist dispute.

In Almyna (1707) Manley continues her interest in female heroism and loyalist Tory politics. The Prologue presents a sort of imperialist poetics, reflexively drawing attention to the genre of heroic drama as a medium for transmitting peculiarly English qualities ('Sense,' manliness, 'Arms'). Here Manley sets up a hierarchy of genres, establishing the empire of honest English drama ('Sense') over modish opera's 'Syren sound,' also referred to in the derogatory tones of the racial or xenophobic slight as 'a dark Translated Nonsense.' In these framing prefatory lines, Manley situates the national superiority in arms together with superior dramatic skills, her Tory propaganda linking artistic truth and good taste with political (here sexual) fidelity, connecting right-thinking with military might. The Prologue pits 'Manlier' English excellence in drama against the 'Modish Tast' [sic] for defective, 'ill Play'd' foreign operas:

Why then such Summs expended for an Art,

Which Nature only does to warmer Climes impart?

And shall to the Support of that alone,

The Art in which we're own'd t'excel, go down?

(Prologue ii) 
These questions are answered by refiguring an old puritan argument against the stage's wantonness, while Manley cleverly repositions the true (English) stage as the chaste wife and false (foreign) opera as the strumpet:

For soon you'd see, were but your Judgements nice,

That Opera's a Strumpet by her Price.

All Nations are for some Perfection Fam'd

Let's not for losing what we have be sham'd:

Let French-men Dance; th'Italians, Sing and Paint,

Perfections we must have from them or want:

Arms we may teach 'em Both, and Both must say,

Our best Diversion is an English PLAY.

(Prologue ii)

After all this careful affirmation of a nationalistic, loyalist agenda, the tragedy's setting is exotically far-flung. It seems significant that Manley's drama of a strong, virtuous, learned woman's ascendancy over patriarchal barbarism is set, as far from the here and now as possible, in that most exotic (yet desirable) of foreign worlds - the Capital of Arabia. Then again, the fantastic aspects of the setting - with its clear connection to the Arabian Nights - would allow for the kind of quasi-satirical refabricating of contemporary gender roles which featured so prominently in Manley's later prose fictions.

Exotic though he may be, the monarch of this distant kingdom is decidedly unenlightened. Almanzor, 'Caliph and Emperor,' represents the worst kind of king, enacting a vicious despotism by committing serial murder and sacrilege in the name of religious law. He orders the deaths of all his wives in quick succession - 'helpless Women / Under the sacred Name and Veil of marriage' (1.1.1). When this ruler of large 'Sway' and 'Despotick' power is about to name his younger brother Abdalla as heir, the young prince's eagerness to claim the beauteous (and learned) Almyna juxtaposes sites of conspicuous consumption in the female bodies who are traded for power. For while Almyna, 'The wonder of our Sex, and pride of hers' (1.1.2), will be given to Abdalla, a rake who has enjoyed then discarded her sister for a richer conquest, she approaches the marriage bed through a system of exchange further marked by the bloodlust of a patriarch who takes female lives in order to pay a debt of allegiance to a deity as brutal as the emperor himself.

Almanzor's ghastly taste in spousal sacrifice represents an extreme example of patriarchal appropriation. His 'Sway' extends to murderous dominion over female bodies, reinforced by religious codes only he can decipher that place women on a level with animals: 
... the Right is his,

To explain what in our holy Alcoran,

Or dark, or deep, or difficult appears,

Hence he expounds, that frailer Womankind,

Have mortal Souls, in common with the Brutes.

Yet Caliph Almanzor styles himself a 'noble Soul,' cautioning Abdalla, 'Conquests, and Pow'r to those not truly good, / Gives only means of doing larger Ills' (1.1.5). This characterization represents a monarch who has lost his way (misled by faulty religious dogma), the rule misdirected disastrously, if only temporarily so. Such an ugly situation could arguably be comparable in Tory eyes to that of the hated Marlboroughs leading Queen Anne by the nose. The propagandist condemnation resonates through most of the play, for what audience could cheer for a grossly muddleheaded monarch who commits 'Murther,' 'Horrid Murther!' perpetually sacrificing innocent souls in the name of doctrinal might? These scenes echo earlier post-Restoration purges noted by observers such as Pepys who chronicled the sight of bodies hanged and quartered after the excesses of Cromwell's MajorGenerals during the Interregnum and James Young (the surgeon) who noted heads and quarters all along his journey from Exeter after Monmouth's Rebellion.

The exotic ceremony of this opening scene demonstrates not only a far-away place of heady Arabian scents and gardens, but also (much closer to home) an imperial state gone askew in a fundamentally wrongthinking way. For this, Manley emphasizes, is a king who goes in for some serious hocus-pocus, with the 'Alcoran' wrapt in a piece of very rich stuff at the centre of it all (1.1.5-6). Is this a monarch swayed by Whiggish religious enthusiasms, perniciously inclined to misinterpretations of the true church? Clearly the denouement requires the audience to see the ruler saved by the love of a good, strong, learned woman Almyna, with its suggestive anagram of Manley's own name. Tory ideology with its message of loyalty to the sovereign is evident, but the political outcome in the drama's closing scene opens up contradictory space which allows for a female figure to shape events. Almyna emerges as a bold, erudite social activist who reforms a cruel system by offering her own body in sacrifice to the Caliph's twisted interpretation of the law. Almyna, one could say, is inspired - not swayed by the more deadly enthusiasms of non-conformist Whiggery, but rather by a natural nobility which enacts her high-born quality, her so-called 'Glory,' a reputation which bespeaks both virtue and spirited resistance to muddleheaded dogma. 
At the end of the play Almyna is the redemptive figure, restoring balance and virtue to the kingdom, the anti-rake facing off the rakish Abdalla who has debauched and abandoned her sister Zoradia. Both Abdalla and Zoradia - each left dead in the final scene - fit the paradigm of earlier plays outlined by Owen: 'Darkness and difficulty in private reflect the paralysis which afflicts the royal subject in public. The contradictions in society are internalized in the family and the self and become self-consuming' (215). Although Almyna finally makes a good marriage, accepting a role in which Canfield might read feminist Glory troped into the figure of the uppity woman tamed by gender dominance, one could also argue that it is left to Almyna to take on the heroic royal mantle of justice and mercy when she begs (even as the mutes are going to strangle her) 'Pardon the Errors of Humanity' and offers up her own life for 'the last of our / Great Emperor's wilful Crimes' (5.1.63).

Manley's final, most well-received play, Lucius, The First Christian King of Britain, was written after what true-blue Tories would have seen as the Hanoverian usurpation and during the Jacobite revolution known as The Fifteen. The tragedy's marshalling of Gallic Chiefs, Alban lords, and Cambrian Princes would have given contemporary audiences plenty of political food for thought. Suggestively, Manley presents a female queen as the agent of succession (Rosalinda a pointedly Christian queen at that) and Lucius (who converts to Christianity for the love of Rosalinda) as the man she successfully chooses to marry secretly (another radical idea). Rosalinda's moves work against convention, since not only is she in mourning for her recently departed husband the rebel King of Aquitaine, but Lucius is seemingly the son of foul Vortimer, her would-be rapist and, after being denied her hand, the murderer of her father. So unusual is the likelihood of Rosalinda succeeding in her bold choice of such a consort that throughout the play we wait for the inevitable fatality as for Felicia in Trotter's Fatal Friendship, but in Manley's play the good queen gets her man. Canfield indicates that while no real class rebellion takes place, at the end the queen of Albany's marriage to the king of Britain is emblematic of England's 'superiority' over a feminized Scotland (Cultural Readings 201).

Yet even if Lucius is Jacobite propaganda, its Tory ideology appears skewed in the representation of kingship as arbitrary and parricidal. Lucius is put in place by a Gallic king who suspends his country's laws and religion to do so, and Lucius accidentally kills Vortimer, the tyrant 'Monster,' who turns out not to be his father after all but his father's murderer. The plot twists make everything work out for the good in the end, but, nevertheless, questions about power, usurpations and regicides remain. In these very contradictions it seems to me the space for the female transmission of power opens up. Rosalinda may not embody 
the rank potency of a libertine hero such as Homais from Manley's first tragedy, but neither is she obliged to claim the transgressive space of rakish appropriation as the sole option available (a role implicated by events early in Manley's own history). Like Almyna, Rosalinda bravely gambles her life to maintain her principles and the succession. When Vortimer's soldiers strike at her husband, she physically interposes and then agrees to captivity in order to save Lucius's life. Vortimer's attempted abduction of Rosalinda is countered with her fierce heroism when she dares natural forces to take up her cause, exhorting the sea to a rage such as her own:

\author{
K. Vor. Away. Now for the Sea \\ Queen. And may it with unbounded Rage receive us. \\ Blow Winds, exert on us your utmost Force, \\ All Nature else be free; Plunge us beneath, \\ Dash us on Rocks: ye cannot be too cruel; \\ Yet spare my Husband, amidst all your Storms. \\ But for this impious King and me, \\ War, Fire, Fury, Blood and Devastation \\ Pursue us, as ye did my wretched Father.
}

Her challenge to the heavens to rain destruction on the rebel group strikes up a bargain with the elements, giving up everything in exchange for her husband's life and abandoning all notions of her 'Honour' which is 'the Care of Heav'n.' Whether or not this smacks of Toryism invoking the threat of civil war in the face of internal corruption, Rosalinda seems to represent a more forcefully heroic type than the bourgeois trope of the self-made woman would allow.

Manley's problem here is not so much that she lets the side down when it comes to gender politics. Perhaps (at the risk of adopting commercial imagery) the question relates more to marketing strategies, for not even a poet of Miltonic proportions can make virtue appear quite as luscious as vice. But the relatively plain face of a victorious Rosalinda does not have to be read as failing the grade in the way Canfield's report card suggests (from Manley 'one might have expected a more enlightened treatment of gender'). Like Behn before her, here Manley engages no less in a revolutionary act of the kind identified by Cixous: this is 'Woman putting herself into the text - as into the world and into history - by her own movement' (245). Paula Backscheider refers to this idea of women writers of the period such as Behn 'renegotiating elements of the patriarchal ideology such as "woman" and woman's "place" as well as things of crucial importance for women's lives such as "satisfactory 
courtship," "good marriage," and options for single women' (83). From the Foucaultian view of power as a cluster of relations, she argues that 'Whenever these negotiations occur, "man," "man's role," and "perfect husband" are renegotiated as well.' Herein the revolutionary agitation occurs.

These female characters demonstrate how Manley offers a critique of corrupt power structures while showing sympathy for women whose marriage choice or sexual expression is limited. In earlier Restoration plays, as Owen indicates, Tory ideology represents 'the family violated by rebels and ambitious plotters' (162), this analysis suggesting an application in Manley's tragedies where order and hierarchy in the family become a way of engaging with political problems of disorder (Owen 162). Perhaps a plastering over of ideological cracks, reconstructing and reinstating Tory ideology after various ruptures in the Stuart cause and the subsequent Whig ascendancy is (among other things) what Manley's heroic tragedies set out to achieve. Arguably, too, these tragedies might fit Benjamin's definition of baroque drama, seeking 'to reduce both its contemporaries and posterity to silence' (56). When Manley states her intention to tip the scales of true English taste away from 'ill Play'd' opera towards heroic drama and 'Nature's force' (Almyna, Prologue), would it be fair to say that her tragedies are 'possessed of an unremitting artistic will' (Benjamin 55) and absolutist? The answer resists monolithic definition. For while the pathos and 'violence' of style are there in full measure, Manley's Tory absolutism comes in a package of contradictions where feminist space opens up and changes the shape of things past, passing or to come.

\section{ELIZABETH HOLLIS-BERRY}

Lakehead University

\section{Notes}

1 Owen explains how "Tory texts see the main threat to sovereignty as emanating not from the throne, but from the "faction" and "ingratitude" " of rebels. She continues, "Faction," a word which occurs frequently in prologues and epilogues, conveys not just criticism of political opposition but hostility to any political activity or interference in the business of kings. Rebels are also guilty of the unnatural crime of ingratitude, since the patriarchal model suggests that subjects should be as grateful for the benefits of kingly government as children are to their parents. The faction and ingratitude of villains is often associated with the wrongful banishment or exclusion of loyal heroes' (131).

2 Apropos Manley's delineation of female rakes and heroes, a similar process of re-negotiation is set out by Backscheider: 'When Behn and other women writers began to modify representation, they were participating in a hegemonic process 
.... Women were seeking to wrest away man's power to define women's nature, needs, aspirations, and acceptable conditions of existence' (83).

3 Admittedly, in The Origins of German Tragic Drama Benjamin's comments concerned baroque drama outside England but his analysis is useful because it outlines shared features, as well as major differences. Ultimately, however, Owen's emphatic comment properly points out that 'Benjamin's description of the political absolutism under which the drama was produced is too absolute for English Restoration politics and society' (18).

4 Since in the available editions of these plays no line numbers are given, I have marked act and scene numbers by the standard method and appended a page number immediately following that of the scene.

\section{Works Cited}

Backscheider, Paula R. Spectacular Politics: Theatrical Power and Mass Culture in Early Modern England. Baltimore: Johns Hopkins UP, 1993.

Benjamin, Walter. The Origin of German Tragic Drama. Trans. J. Osborne. London: New Left Books, 1977.

Canfield, J. Douglas. 'Shifting Tropes of Ideology in English Serious Drama, Late Stuart to Early Georgian.' Cultural Readings of Restoration and Eighteenth-Century English Theater. Ed. J. Douglas Canfield and Deborah C. Payne. Athens \& London: U of Georgia P, 1995. 195-227.

Cixous, Helene. 'The Laugh of the Medusa.' Repr. in New French Feminisms. Ed. Elaine Marks and Isabelle de Courtivron. Amherst: U of Massachusetts P, 1980. 245-64.

Doody, Margaret Ann. The Daring Muse: Augustan Poetry Reconsidered. Cambridge: CUP, 1985.

Manley, Delarivier. Almyna: Or the Arabian Vow. London: William Turner, 1707. . Lucius, The First Christian King of Britain. London: John Barber, 1717 The Royal Mischief. The Female Wits. Ed. Fidelis Morgan. London: Virago, 1981. 209-261.

Markley, Robert. 'Be impudent, be saucy, forward, bold, touzing, and leud': The Politics of Masculine Sexuality and Feminine Desire in Behn's Tory Comedies.' Cultural Readings of Restoration and Eighteenth-Century English Theater. Ed. J. Douglas Canfield and Deborah C. Payne. 114-140.

Marx, K. The Eighteenth Brumaire of Louis Bonaparte. New York: International, 1963.

Owen, Susan J. Restoration Theatre and Crisis. Oxford: Clarendon, 1996.

Pollak, Ellen. The Poetics of Sexual Myth: Gender and Ideology in the Verse of Swift and Pope. Chicago: U of Chicago P, 1985.

Staves, Susan. Players' Scepters: Fictions of Authority in the Restoration. Lincoln \& London: U of Nebraska P, 1979.

Todd, Janet. Introduction to Aphra Behn: Oroonoko, The Rover, and Other Works. London: Penguin, 1992. 